\title{
PENGARUH LATIHAN FISIK TERHADAP JUMLAH SEL FIBROBLAST DAN TEBAL SERAT SHARPEY PADA TENDON ACHILES
}

Oleh: Sri Sumartiningsih

Dosen Pendidikan Kesehatan dan Rekreasi FIK UNES

\section{Abstrak}

Latihan fisik dapat mengakibatkan peningkatan fungsi sistem tubuh, khususnya pada sistem musculoskeletal. Salah satunya dapat dilihat dari kekuatan daya rentang tendon. Tendon adalah struktur jaringan ikat padat yang berbentuk silinder, kadangkala pipih, yang menghubungkan otot dengan tulang.

Latihan yang secara berulang sesuai dosis, ritme, frekwensi dan intensitas dari tiap indvidu akan berpengaruh terhadap jumlah sel fibroblast dan tebal serat sharpey pada tendon.

Kata kunci: latihan fisik, sel fibroblast, tebal serat sharpey, tendon achiles

Latihan fisik mampu menghasilkan adaptasi yang dapat meningkatkan fungsi berbagai sistem tubuh (Wilmore, 1994). Pada sistem musculoskeletal, latihan fisik memperlihatkan peningkatan terhadap daya rentang tendon (Fox, 1993).

MEDIKORA Vol.III, No 2, Oktober 2007: 273-287 
Woo (1994) menyatakan bahwa kekuatan daya rentang tendon ditentukan oleh tingginya prosentase kolagen. Salah satu pemicu terjadinya peningkatan produk kolagen pada tendon adalah stres mekanisme. Jenis latihan fisik yang dapat menimbulkan stress mekanis diantaranya yaitu jalan, lari, loncat dan renang (Thibodeu, 1994).

Dari latar belakang tersebut diperlukan kajian yang lebih mendalam untuk mengetahui pengaruh latihan fisik terhadap sel fibroblast.

\section{LATIHAN FISIK}

Aktivitas fisik adalah semua bentuk gerakan otot, Latihan fisik adalah aktivitas fisik yang spesifik, dan pelatihan fisik adalah latihan yang dilakukan secara berulang. (harjanto, 2003, Setyawan, 1996).

Komponen (dosis) latihan fisik yang terdiri dari intensitas, frekuensi dan ritme (contoh; interval dan kontinyu), durasi dan modus atau jenis latihan (Wilmore, 1994, Harjanto, 2003).

Dosis latihan merupakan takaran dari pemberian beban latihan terhadap tubuh. Factor yang mempengaruhi latihan antara lain: intensitas latihan, frekuensi latihan, dan durasi latihan (Fox, 1993). 
a. Intensitas latihan

Intensitas menunjukkan sebuah kualitas elemen latihan. Menurut Bompa (1994) Berdasarkan berat badan intensitas fisik dapat dibagi menjadi: 1) latihan fisik intensitas ringan (dengan pemberian beban sebesar 3\% berat badan), 2) latihan fisik intensitas sedang (dengan pemberian beban sebesar 6\% berat badan) dan latihan fisik intensitas berat (dengan pemberian beban sebesar $9 \%$ berat badan).

Cara menentukan intensitas latihan dapat dilakukan dengan metode denyut nadi dan metode yang berkonsep pada nilai ambang aerobic (Fox, 1993).

b. Frekuensi latihan

Frekuensi latihan dapt dilakukan 1 kali, 2 kali, 3 kali, 4 kali.dan 5 kali perminggu, tergantung tujuan yang ingin dicapai (Fox, 1993).

c. Durasi (lama) latihan

Lama latihan dpat diartikan sebagai rentang waktu yang dapat berupa berapa menit atau berapa jam latihan dilakukan dalam setiap kali latihan dan dapat pula diartikan berapa minggu atau berapa bulan suatu program latihan berlangsung (Fox, 1993, Bompa, 1994).

MEDIKORA Vol.III, No 2, Oktober 2007: 273-287 


\section{ANATOMI TENDON}

Tendon adalah struktur jaringan ikat padat yang berbentuk silinder, kadangkala pipih, yang menghubungkan otot dengan tulang. Tendon meneruskan gerakan kontraksi otot pada tempatnya melekat (Tubiana, 1988). Tendon merupakan jaringan ikat berwarna putih mengkilat, dan fleksibel, ia melekat pada tulang sehingga dapat langsung menggerakkan sendi (Newmeyer, 1979).

Tendon achiles merupakan tendon paling kuat dan paling besar dalam tubuh. Tendon achiles terletak di punggung kaki bagian bawah. Tendon ini menghubungkan otot soleus dan gastronemius menuju ke calcaneus. Pada saat seseoang melakukan latihan fisik, tendon achilles aktif bergerak (Lester, 2003).

Woo (1994) menyatakan bahwa sebagai jaringan ikat untuk menghubungkan otot pada tulang dan untuk mewujudkan efek kontraksi otot, tendon tidak dapat membangkitkan kekuatan tetapi merupakan transmitter yang baik bagi daya otot. Tiap unit areanya lebih kuat dari pada otot, daya rentangnya sebaik daya rentang tulang, meskipun sangat fleksibel, serabutnya mampu menahan tegangan sehingga energi kontraktil otot tidak hilang selama pengiriman ke insersi atau pelekatan. 


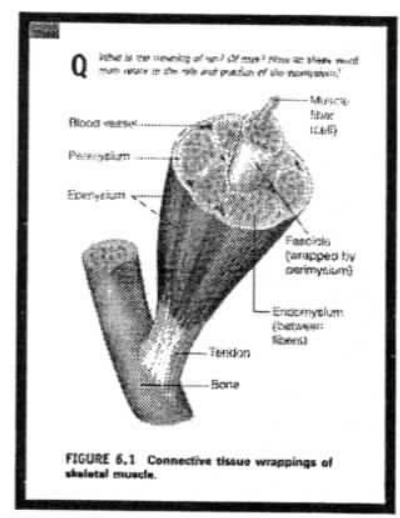

Gambar 1. Anatomi Tendon

1. Stuktur tendon

Tendon termasuk dalam klasifikasi jaringan ikat padat, dimana ditemukan serat-serat kolagen dan terdapat sel-sel fibroblast diantaranya (Craigmyle, 1986).

Menurut Tubiana (1988) tendon memiliki struktur jaringan ikat yang terorganisasi, terdiri dari kumpulan seratserat kolagen yang tersusun parallel yang dipisahkan oleh septa penghubung yang disebut endotendineum, septa-septa membawa pembuluh darah dan syaraf, beberapa serat kolagen atau berkas-berkas tendon primer membentuk suatu fascicle atau berkas tendon sekunder yang dibungkus oleh jaringan ikat, dinamakan peitendineum. Tendon sendiri terdiri dari sejumlah fascicle dan diliputi oleh jaringan ikat yang relatif tebal serta mengandung pembuluh-pembuluh darah, saraf, lemak yang disebut epitendineum.

MEDI KORA Vol.III, No 2, Oktober 2007: 273-287 


\section{Kolagen}

Kolagen dapat dibedakan atas lima jenis atau tipe yang masing-masing berbeda dalam komposisi rantai alphanya, yaitu 1) tipe I, original collagen sebagian besar terdapat pada organ kapsula, jaringan trabekular, kulit, tendon dan tulang, 2) tipe II, terdapat pada tulang rawan elastin dan hialin, 3) Tipe III, terdapat pada dinding arteri, 4) tipe IV, terdapat pada membran basal, 5) Tipe V, tersebar tidak menentu (Craigmyle, 1986).

Kolagen merupakan protein yang terdiri dari tiga asam amino, ia merupakan konstituen utama sebagian besar jaringan ikat kolektif. Pada tendon konstituen utama adalah kolagen tipe I (original collagen), kolagen mengandung kosentrasi glisin yang tinggi (33\%), prolin (15\%) dan hydroxpoline (15\%) sehingga hampir $2 / 3$ struktur primer rantai kolagen mengandung tiga asam amino tersebut (Threy, 1984)

Serat kolagen sangat kuat dan tahan terhadap regangan, tetapi sedikit fleksibel dan berkas tersebut sering terlihat bergelombang (Craigmyle, 1986). Kolagen berfungsi menyediakan kekuatna dan integritas structural dari berbagai jaringan serta organ dalam tubuh. Untuk putus atau 
rupturnya serabut kolagen yang berdiameter $1 \mathrm{~mm}$ saja memerlukan beban $10 \mathrm{~kg}$ hingga $40 \mathrm{~kg}$ (Threy, 1984).

\begin{tabular}{|c|c|}
\hline $\begin{array}{l}\text { Gambar 2. Tendon, kollagen } \\
\text { Fibers }\end{array}$ & $\begin{array}{l}\text { Gambar 3. Te } \\
\text { cells }\end{array}$ \\
\hline
\end{tabular}

3. Sel Fibroblast

Fibroblast merupakan jenis sel yang paling umum, berbentuk fusiform atau stellata dengan inti lonjong, sitoplasmanya bersifat basofil disebabkan banyaknya rough endoplasmic reticulum, mereka menghasilkan serat kolagen reticular dan elastin (Craigmyle, 1986).

a. Morfologi Fibroblast

Fibroblast merupakan sel yang besar, agak memipih, seringkali agak berbentuk bulat panjang atau avoid, disertai tonjolan-tonjolan sitoplasma tumpul yang bercabang. Intinya lonjong menyerupai bentuk dari selnya, dapat diperlihatkan

MEDI KORA Vol.III, No 2, Oktober 2007: 273-287 
dengan beberapa cara perwarnaan, misalnya dengan pembuatan sediaan bentangan jaringan ikat yang diwarnai dengan cata basa seperti methylene blue, dilihat dengan miskroskop cahaya, sitoplasma fibroblast yang tercat pucat pada pewarnaan ini seringkali meluas secara tak teratur dari badan sel dalam bentuk tonjolan-tonjolan. Fibroblast lazimnya menunjukkan seperti cerutu (fusiform shape), intinya avoid dan tampak pucat dimana butir-butir kromatin yang halus tersebar dengan pengecatan H.E. (Kusumo, 1991).

b. Ultra Struktur Fibroblas

Sel fibroblast dengan pengamatan menggunakan mikoskop electron menunjukkan adanya peningkatan yang nyata dalam jumlah reticulum endoplasmic kasar dan juga dari pada ribosom-ribosom bebas yang merupakan tempat dimana rantai alpha protokolagen dibuat. Disamping itu pada stadium aktif tampak peningkatan jumlah transfer vesicles yang mengankut rantai alpha dari kolagen ke dalam sakusaku kecil atau golgi saccules, maka bagian terntentu dari transfer vesikel ini berubah bentuknya menjadi gelembung berbentuk kecil yang melebar, serta mengandung filamenfilamen halus. Benang-benang halus ini kemudian menjadi lurus dna saling sejajar serta gelembung-gelembung yang mengandungnya menjadi silindik. Bila isi dari gelembung ini 
lambat laun memadat, maka gelembung-gelembung ini tampak sebagai gelembung-gelembung sekretorik atau secretory vesicles, hingga pada hakikatnya prokolagen yang dilimpahkan pada permukaan sel lambat laun akan berubah menjadi molekul-molekul tropokolagen yang akhirnya menjadi fibril-fibril kolagen (Kusomo, 1991).

\section{c. Fungsi Sel Fibrolast}

Fibroblast berperan secara aktif dalam sintesa dari pada protein yang menjadi materi dasar untuk pembentukan bahan antar sel yang berbentuk maupun yang amorof, fibroblast berasal dari differensiasi dari pada sel-sel mesenchyme (Kusumo, 1991).

Fibroblast secara aktif menghasilkan substansi inter sel, sel ini memiliki juluran sitoplasma dan inti tunggal berbentuk bulat umumnya terlihat jelas, yang menandakan adanya sintesa protein secara aktif, fibroblast ini dapat melepaskan produk sekresinya dari sembarang tempat pada permukaan selnya. Peran fibroblast ini sebagai pembentuk kolagen sangat dikenal, dalam tendon fibroblast juga memperbaiki dan mengganti fibril kolagen (Cormack, 1992).

d. Serat sharpey (Insesi tendon pada tulang)

Perlekatan tendon dengan tulang di daerah insersionya begitu kuat karena serat kolagen masuk ke dalam kortek

MEDIKORA Vol.III, No 2, Oktober 2007: 273-287 
tulang dan menyebar di dalamnya, disebut dengan serat Sharpey. Begitu kuatnya ikatan tersebut, sehingga apabila terjadi tarikan tendon yang sangat kuat dapat menyebabkan avulse dari tulang (Salter, 1982).

Cormack (1992) menyatakan bahwa insersi tendon yang semula pada tulang kecil akhirnya menjadi insersi pada tulang besar. Karena itu sebagai akibatnya tempat perlekatan tendo yang terdahulu makin lama makin terpendan dan bila berkas kolagen insersi tendo terpendam dalam pertumbuhan tulang maka disebut sebagai serat sharpey.

\section{PENGARUH LATIHAN FISIK TERHADAP TENDON}

Tujuan utama dari latihan adalah untuk mengembangkan fungsi ogan tubuh dna kemampuan biomotor, oleh karena itu latihan akan mempengaruhi organorgan dalam tubuh (Bompa, 1994).

Beberapa ahli mengemukakan bahwa, secara morphologis latihan fisik mempengaruhi perubahan yang nyata selama pertumbuhan organisme. Jumlah dari inti sel fibroblast dan berat dari tendon tikus meningkat. Perubahan secara biokimia juga dilaporkan bahwa latihan mempengaruhi peningkatan aktvitas enzi mitogenik, demikian juga sintesa kolagen pada tendon (Saltin, 1986). Selanjutnya 
Fox (1993) menyatakan latihan fisik memperlihatkan peningkatan terhadap perubahan kekuatan tendon.

Birch (1997) pada penelitiannya menyatakan bahwa tendon menyimpan energi panas selama bergerak dalam latihan meskipun suhu yang terjadi sangat cepat, dimana fraksi sel fibroblast tendon sangat tahan terhadap panas dan tidak mungkin terjadi kematian sel fibroblast selama latihan fisik.

Sedangkan menurut Thibadecu (1994) latihan fisik dapat menimbulkan stress mekanis. Stress mekanis dapat menyebabkan mekanisme penting yaitu mekanotansuksi pada sel dan memulai intraselular sinyaling, meningkatkan pertumbuhan sel dan menentukan morfologi dan arsitektur pada beberapa tipe sel. Beberapa sel menunjukkan respon yang berbeda tehadap stress mekanis dan dasar molekuler untuk mekanotransduksi. Pada tendon, respon mekanotrasduksi akibat stress mekanis adalah menstimulasi integrin untuk mentransmisikan sinyal tranduksi dai luar ke dalam sel fibrolas. Sel fibroblast merupakan sel penting fungsinya dalam mensintesi kolagen (Kjaer, 2004).

Ditinjau dari konsep factor pertubuhan fibroblast dasar, akibat dari rangsangan latihan fisik terjadinya peningkatan aktifitas sistem vaskularisasi dan kardiorespirasi, latihan

MEDIKORA Vol.III, No 2, Oktober 2007: 273-287 
mengakibatkan fibroblast pada tendon aktif mengabsorbsi pemakaian nutrisi dan unsure pembangun kimiawi yang dibutukkan melalui pembuluh darah, sehingga sel lebih banyak menghasilkan substansi inter sel, kebutuhan oksigen yang diperlukan untuk memperoleh energi essensial sangat cukup guna mengoksidasi bahan makanan dengan respirasi sel akibat dari latihan. Hal ini sejalan dengan factor pertumbuhan fibroblast dasar (bFGF), dimana latihan merangsang aktifitas enzim hyaluronidase sehingga meningkatkan jumlah mitogenik, peptide dan asam amino yang merupakan factor dasar pertumbuhan fibroblast. Dengan melalui beberapa proses akhirnya sel fibroblast berkembang dengan menghasilkan substansi intersel sendiri yaitu terjadinya peristiwa pertumbuhan sel akibat dari rangsangan latihan (Chandrasoma, 1991).

Latihan intensitas berat sinyal transduksi yang dtransmisikan dari luar ke dalam sel fibroblast lebih tinggi dibandingkan dengan latihan intensitas ringan, sehingga efek sinyal tersebut juga lebih tinggi pada latihan intensitas berat. Sel fibroblast dan tebal serat sharpey memperlihatkan ada kontribusi bermakna respon perubahan akibat perlakuan, sedangkan luas area potongan melintang tidak menujukkan 
kontribusi yang bermakna respon perubahan akibat latihan (Yulian, 2007).

\section{KESIMPULAN}

Dari hasil kajian pustaka diatas tentang pengaruh latihan fisik terhadap jumlah sel fibroblast dan tebal serat sharpey pada tendon achiles didapatkan kesimpulan sebagai berikut:

1. Latihan fisik dapat meningkatkan jumlah sel fibroblast dan tebal serat sharpey

2. Peningkatan jumlah sel fibroblast dan tebal serat sharpey tergantung dari intensitas latihan, lama latihan dan dosis latihan

\section{Daftar Pustaka}

Bompa TO, 1994. Theory and Metodology of Training The Key to Athletic Performance. Dubuque lowa: Kendal/Hunt Publishing, pp 14-20.

Birch HL, Wilson HM and Goodship AE, 1997. The Effect of Execise-Induced Localised Hypertermia on Tendon Cel Survival. J. Ex. Biol. 200: pp.1703-1708

Brunker P, Khan K, 1993. Clinical Sport Medicine. Sydney: McGraw Hill Book Company. Pp 12-14. 
Chandrasoma P, 1991. Concise Pathology, a lange medical book. Prentice-Hall International Inc. California, PP. 81-85

Craigntyle MBL, 1986. Coloring atlas Histologi. Nethelands: Wolfe Medical Publication Med. Ass, Vol 81 No.7. pp 353363.

Fox, 1993. Human Psyiology. 6th edition. Boston: McGraw-Hill Companies.

Harjanto, 2003. Petanda Biologis dan Faktor yang mempengaruhi Derajat Stres Oksidatif pada latihan olahraga aerobic sesaat. Surabaya: Disertasi Program Doktor Pascasarjana Universitas Airlangga. Hal 1-3.

Kjaer Michael, 2004. Role of Extracellular matrix in adaption of tendon and skeletal muscle to mechanical Loading. J Phyaiol rev 84. http://physrev.physiology.org/cgi/content/full/84/2/649 diakses tanggal 21 Juli 2008.

Kusumo J.S, 1991. Keempat jaringan pokok tubuh. Surabaya: Laboratorium Anatomi dan Histologi Fakultas Kedokteran Universitas Airlangga

$\mathrm{S}$

Lester gayle, 2003. Tendon Biology. http://www.sunvalleyworkshop.org diaktes tanggal 21 juli 2008.

Newmeyer WL, 1979. Primary Care of Hand Injury. Lea \& febiger. Philadelphia. Pp 160-162. 
Setyawan S, 1996. Pengaruh Latihan Fisik Aerobik dan anaerobic terhadap respon ketahanan tubuh. Disertasi. Program Pascasarjana Universitas Airlangga. Hal 8-13, 1617.

Thibodeu. 1994. Structure and Function of Body. USA: Mosby Year Book. Inc. pp 79-85.

Threy SL, 1984. Othopeaedics Principles and Application. Philadephia: Lippincott Company. Pp. 113-114.

Wilmooe JH, Costill DL. 1994. Physiology of Sport and Exercise. USA: Human Kinetics. Pp 3-5.

Woo S, et all. 1994. Anatomy Biology And Biomechanis of Tendon, Ligament And Meniscus. American Academy of Orthopaedic Sugeone. Pp 47-49.

Yulian W U. 2007. Efek Pemberian Latihan Renang Intensitas Ringan Dibanding Intensitas Berat Terhadap Luas Area Potongan Melintang, Jumlah Sel Fibroblast Dan Tebal Serat Sharpey Pada Tendon Achilles Tikus Putih (Rattus Novergivus Galur Wistar) Jantan. Surabaya. Tesis. Program Pascasarjana Universitas Airlangga. Hal 60-62

MEDI KORA Vol.III, No 2, Oktober 2007: 273-287 